\title{
The (Real)politiks of Culture: U.S. Cultural Diplomacy in Unesco, I946-1954*
}

The United Nations Educational, Scientific, and Cultural Organization (Unesco), ${ }^{1}$ which was founded in I946, has long had a reputation as one of the more contentious, politically divided, and ineffective organs of the United Nations. It is familiar to many scholars as an illustration of the failure of multilateralism and the controversies of Third World nonalignment in the I970s. However, Unesco had been hampered by political controversy from its earliest years as tensions emerged over the deepening pragmatism of America's Cold War cultural diplomacy. This article explores the politicization of culture during Unesco's first nine years, focusing on U.S. efforts to generate an antiCommunist consensus within Unesco and exploring the effect of U.S. policies on its Western geopolitical allies.

Despite the cosmopolitan hopes of its founders-educators and policymakers who envisaged Unesco as cultivating global humanism beyond the narrow concerns of politics - within a few years the regular conferences and diplomatic channels of Unesco had been overshadowed by political pragmatism and the pursuit of cultural prestige. The most conspicuous source of the politicization of culture within Unesco in this period was the United States, which had the financial capacity and institutional dominance to shape the organization's agenda and principles. The United States also had an obvious interest in shaping global cultural relations as the Cold War conflict emerged, and U.S. diplomatic strategy in Unesco reflects key shifts in how its cultural interests were framed according to its broader ideological objectives. In Unesco's infancy, U.S. policymakers were shaped by the "cultural internationalism" of the early postwar years, sentiments which fitted easily into the humanistic basis upon which Unesco was founded. However, within two years the U.S. delegation had become preoccupied with the "scourge" of Cold War neutralism among Unesco members, and increasingly sought to apply to Unesco the instrumental approach

*I wish to thank Sally Kuisel from the US National Archives, College Park MD, for alerting me to the Unesco Decimal Files, as well as John Forge, Jacinta O'Hagan, Joel Quirk and especially Diplomatic History's two anonymous referees for their incisive comments on earlier drafts of this article. Thanks are also due to the Department of International Relations, RSPAS, Australian National University, which supported my travel.

I. "Unesco" is not capitalized, in keeping with the usage in Unesco's documentation.

Diplomatic History, Vol. 30, No. 2 (April 2006). (C) 2006 The Society for Historians of American Foreign Relations (SHAFR). Published by Blackwell Publishing, Inc., 350 Main Street, Malden, MA, 02 I48, USA and 9600 Garsington Road, Oxford OX 4 2DQ, UK. 
to cultural relations that was taking hold across the spectrum of U.S. cultural and public diplomacy. ${ }^{2}$

The United States' attempts to shape the Unesco agenda for instrumental purposes were especially provocative because the USSR was not a member of the organization before I954. Communist interests were represented only by a diplomatically weak handful of Eastern European delegations. ${ }^{3}$ As a result of this imbalance, the United States' Cold War diplomacy in the early postwar period was seen by erstwhile allies as an unwarranted political intrusion into Unesco's "apolitical" cultural and educational role. By I948 the United States faced opposition from a "neutralist" caucusing group in the Unesco General Conference, composed of Latin American and Middle Eastern states. The "freedom of information" principles promoted by the United States from I 946 also soon became controversial, as weaker states feared U.S. dominance in global information would simply increase as a consequence of the policies. Even more contentious among the members of Unesco were U.S. efforts in 1950 to extract a commitment from Unesco to supply "international information" in support of the Korean War. The United States was almost totally isolated in this endeavor; even the normally supportive British, whose overall policy was one of public unity with the United States, questioned the desirability and practicality of giving Unesco over to "short term activities" such as public information. ${ }^{4}$ Membership and representation issues were further sources of controversy. These incidents provide a framework for charting the rise of the United States' Cold War cultural realpolitik and its destabilizing impact on cultural internationalism and the Western bloc.

Edward H. Buehrig, commenting in the I970s on Unesco's periodic controversies, suggested that Unesco's “tribulations" stemmed from two fundamental contradictions, which provide a useful illustration of key dynamics in the I946I 954 period. The first was an inherent tension between the internationalism of Unesco's aims and its practical impact on realms such as national education, which are "by nature parochial" and are implicated in the forging of national differences rather than internationalism. The second contradiction was procedural, arising from the cumbersome multilateralism and voluntaristic networks that Unesco relied upon to function, and its simultaneously ostentatious hopes

2. Unesco Relations Staff, Paris Embassy, "Records of Activities in Unesco House for the Week Ending August 4, I950," 9 August 1950, 5, Records of the Unesco Delegation I950I 954, Paris Embassy, France, Records of the Foreign Service Posts of the Department of State (hereafter FSP), Record Group (hereafter RG) 84, National Archives at College Park, College Park, Maryland (hereafter NA). On the broader context of U.S. cultural diplomacy, see Frank Ninkovich, The Diplomacy of Ideas: U.S. Foreign Policy and Cultural Relations, I938-195o (Cambridge, UK, I98I); Alan Heil, Jr., Voice of America: A History (New York, 2003).

3. These were Czechoslovakia, Hungary, Poland, and Yugoslavia. On U.S. "guesswork" and Soviet intentions, see Chicago Daily Tribune, "Unesco Is Seen as Peace Agent by Dr. Stoddard," I May I 947.

4. Telegram from Foreign Office to Washington, io August I950; "Unesco and the Korean Situation," FO37 I/8890 I, UK National Archives, Public Record Office, Kew. 
for fostering global solidarity. ${ }^{5}$ This article focuses on the first issue: a basic conceptual tension posed within Unesco by the lack of common global cultural interests and the elasticity of cultural internationalism as a doctrine, as shown by terms upon which political disputes were articulated in the I946-I954 period. The second issue of multilateralism and voluntarism is methodologically important in the context of this discussion, because Unesco's procedural structure has generated ample documentary evidence of different actors' intentions. The most useful accounts of Unesco's development have in one way or another addressed the issues encompassed by Buehrig's twin contradictions, though many have tended to focus on later periods in Unesco's history. For instance, James P. Sewell's Unesco and World Politics focuses on institutional behavior in Unesco, sketching the tension between the functions intended for Unesco and its failure to bind states to effective action. ${ }^{6}$ Other accounts that explore the perceptions of different national actors in Unesco include Jan Kolasa's analysis of European intellectual cooperation in the interwar period and its impact on British and French approaches to Unesco ${ }^{7}$ and Sagarika Dutt's study of politicization, which offers some important insights into the forms of controversy that have resurfaced in Unesco's history. Dutt, writing in I995, explored the extent to which membership controversies between 1946 and 1959 served as a platform for the articulation of different actors' contending "universalisms," a helpful concept in the context of the period discussed here. ${ }^{8}$ Clare Wells identifies similar trends in patterns and forms of controversy in Unesco. ${ }^{9}$ But it is also the case that these two accounts of politicization might be usefully supplemented by a study of U.S. intentions in the early Cold War period, for they have not traced the extent to which the emergence of Cold War politics within Unesco was a reflection of America's cultural realpolitik in broader spheres of its cultural and public diplomacy. Similarly, T. V. Sathayamurthy's I964 study of the political disputes within Unesco lacks a sufficiently detailed historical discussion of the emergence of Cold War realpolitik, particularly in terms of the complexity of the United States' relationship with its Western allies. ${ }^{10}$

By drawing attention to some of the broader dynamics of U.S. cultural relations policy, especially the shift characterized by Akira Iriye as the denouement of humanistic cultural internationalism into self-regarding and narrow

5. Edward H. Buehrig, "The Tribulations of Unesco," International Organization 30, no. 4 (Autumn 1976): 679-80.

6. See Sewell's account of Samuel Huntington's institutional theory in James P. Sewell, Unesco and World Politics: Engaging in International Relations (Princeton, NJ, 1975), I97-8.

7. Jan Kolasa, International Intellectual Cooperation: The League Experience and the Beginnings of Unesco (Wroclaw, Poland, I962).

8. Sagarika Dutt, The Politicization of the UN Specialized Agencies: A Case Study of Unesco (Lewiston, NY, 1995), 43-4.

9. Clare Wells, The UN, Unesco and the Politics of Knowledge (London, 1987).

Io. T. V. Sathayamurthy, The Politics of International Cooperation: Contrasting Conceptions of Unesco (Geneva, I964), 91. 
sentiments of cultural nationalism, ${ }^{\text {II }}$ I supplement existing Unesco literature on the development of U.S. policy and diplomatic strategy in this period. The shift toward a more instrumental approach to cultural diplomacy can be shown to have impacted significantly on the United States' fellow members of Unesco; the increasingly critical French delegation and emerging "post-colonial" bloc serve as obvious examples, as does the quiet but concerned diplomacy of the British. In I95 I, for example, one UK policymaker informed the State Department's Charles Thomson of the Foreign Office's mystification that "the U.S. seem to be trying to achieve peace as a commodity attainable by direct effort, instead of expecting it to grow as a by-product of other peaceful activities," and speculates that a "philosophical debate lies at the root of such differences as we have with the U.S." ${ }_{\text {I2 }}$

In addition to supplementing the existing Unesco literature, the argument here sits alongside recent histories of the Cold War articulated in this journal and elsewhere, which show how processes associated with culture and perception have shaped international politics. The work of Akira Iriye, Michael Hunt, Emily Rosenberg, and Frank Ninkovich constitute a pioneering research agenda on these aspects of U.S. foreign policy. From these early accounts a vibrant second wave of scholarship has been launched, exploring in broader geographical and historical contexts the ways in which issues of gender, information, national identity, philanthropy, consumerism, education, and academia shaped postwar global politics. ${ }^{13}$ The case of Unesco adds to this literature by providing a multilateral perspective on the politics of culture in the postwar period. Furthermore, the Unesco case provides some useful insights in relation to recent

I I. Akira Iriye's exceptional Cultural Internationalism and World Order highlights this tension between (progressive) cultural internationalism and (self-regarding) cultural nationalism over the first decades of the twentieth century. His helpful distinction is adopted here. Akira Iriye, Cultural Internationalism and World Order (Baltimore, MD, I997). Julie Reeves explores the academic background to the shift from humanism to pragmatism (or "anthropological" theories of culture) in cultural relations. Julie Reeves, Culture and International Relations: Narratives, Natives and Tourists (Oxford, 2004). Ninkovich's Diplomacy of Ideas remains the touchstone study of the formation of U.S. cultural foreign policy in this period.

I 2. Letter to Alan Dudley from Richard Cowell, i I April I95 I; "Activities of 'Fellow Travellers' in the Unesco Secretariat," FO37 I/88294, UK National Archives, Public Record Office, Kew.

I3. There are too many examples of cultural history to note them all here-a survey of this journal over the last fifteen years will turn up many outstanding articles. Illuminating booklength studies of culture and American foreign relations not cited elsewhere in this article include Liping Bu, Making the World Like Us: Education, Cultural Expansion, and the American Century (Westport, CT, 2003); Walter Hixon, Parting the Curtain: Propaganda, Culture and the Cold War (New York, I997); Gay E. Kraske, Missionaries of the Book: The American Library Profession and the Origins of United States Cultural Diplomacy (Westport, CT, 1985); Richard Pells, Not Like Us: How Europeans Have Loved, Hated, and Transformed American Culture since World War II (New York, I997); Emily S. Rosenberg, Spreading the American Dream: American Economic and Cultural Expansion, I89o-I945 (New York, I982); Giles Scott Smith, The Politics of Apolitical Culture: The Congress for Cultural Freedom and Postwar American Hegemony (New York, 2002). 
historical perspectives on Cold War multilateralism. William Hitchcock, for example, has recently explored French influence in the construction of the postwar European order, noting that the use of institutions and sheer diplomatic skill ensured that France "stood with more real influence on the continent of Europe" than would be expected from its devastated economic and military capabilities. ${ }^{14}$ The image of French diplomacy in Unesco from U.S. and UK sources outlined here supports Hitchcock's observations about the nature of French diplomatic strategy in the postwar period, but it shows less conclusively that France was successful in achieving cultural influence. While the French delegation made known their displeasure over U.S. hegemony throughout the early Cold War, archival evidence gathered here suggests that French criticisms had only a limited impact on outcomes. Only when France worked through the postcolonial voting bloc did it seem to have much chance at parrying U.S. dominance in Unesco.

Planning for a postwar institution to coordinate educational and cultural reconstruction began in 1942 with the establishment of the London Conference of Allied Ministers of Education (CAME). CAME brought together exiled ministers and diplomats from the Continent, UK educators and cultural figures, and staff of the British Council and Ministry of Education (the latter hosted the conference), to discuss the rehabilitation of democratic and cultural institutions in postwar Europe. Within two years, the conference was broadened into consideration of a permanent educational and cultural organization of worldwide scope. ${ }^{15}$ This was signified by the inclusion in mid-I 943 of eight new provisional members of the conference, which included as observers the United States, USSR, China, India, and four British Dominions. ${ }^{16}$ The inclusion of these new members was a productive development: proposals adopted at the plenary session of CAME in October led to the establishment of an executive bureau and a set of clearer constitutional proposals. One year later, at the instigation of the Chinese delegation to Dumbarton Oaks, the London proposals were linked to the planned United Nations Organization. ${ }^{17}$ However, the USSR also withdrew from CAME within a year, and suggestions about the motive remain a source of speculation. One historical account has stated they feared the proposed agreements would interfere in the Soviet national education system, another suggests that a relatively minor dispute over the timing of the Unesco founding conference in 1945 had settled the issue of Moscow's nonparticipation. ${ }^{18}$

I4. William I. Hitchcock, France Restored: Cold War Diplomacy and the Quest for Leadership in Europe, 1944-I954 (Chapel Hill, NC, I998), 203, Conclusion.

I 5. "Science" was a relatively late addition to the framework of Unesco, and plays a relatively minor part in the story told here because it was a less controversial area of Unesco's program as compared with information and culture.

I6. These were South Africa, Canada, Australia, and New Zealand.

I7. See Kolasa, International Intellectual Cooperation, I35.

I8. On education see Sewell, Unesco and World Politics; John A. Armstrong, "The Soviet Attitude toward Unesco," International Organization 8, no. 2 (May I954): 2 I 7-8. 
State Department and administration officials were prominent in articulating the principles of global interdependence that were increasingly infusing the CAME proposals. The dominant view among cultural planners in the State Department was that under conditions of deepening international interdependence, cultural diplomacy was an indispensable platform from which to communicate America's intentions and ensure future security. ${ }^{19}$ As one departmental spokesperson emphasized: "Without the intellectual tools to which our civilization has become accustomed, economic and social disorganization is intensified and moral despair easily sets in . . . this Government should participate in an international program to help the war-torn countries . . in repairing the moral, spiritual and physical damage." ${ }^{\circ \circ}$ Another (internal) State Department memorandum similarly defined U.S. intentions, stressing the need for "a greater consensus among the peoples of the world in the field of ideas and values." Official British sentiment reflected more modest hopes than the U.S. delegates. One Foreign Office source from 1946 noted that a cautious definition of Unesco's "proper functions" would be essential, so as to ensure that Unesco remained "international" in its decision making, given that Unesco's capacity to confer legitimacy on members was liable to provoke attempts at exploitation for national gain. ${ }^{22}$

The founding conference of Unesco was held in London during November I $945 .{ }^{23}$ Prime Minister Clement Atlee opened the meeting with a testament to global humanism that provided the substance of the Unesco constitution's famous preamble, stating that "wars begin in the minds of men." Yet as the national delegations arrived in London, the planning process became mired in disputes over national prestige and cultural influence. The main symptom of this emerging pragmatism was a dispute over the British/American draft constitution and the French contre-project. French attempts to secure a strong position in Unesco were infused with the spirit of political self-assertion that had accompanied the formation of Charles de Gaulle's provisional government, and the French delegation frequently voiced claims to international cultural leadership based on the French role in the League of Nations Institute for Intellectual Cooperation. A sarcastic communiqué from the French Foreign Ministry to

I9. Christina Klein, Cold War Orientalism: Asia in the Middlebrow Imagination, I945-I96I (Berkeley, CA, 2003).

20. H. S. Villard, "The Positive Approach to an Enduring Peace," Department of State Bulletin 2256 (28 January I945): I40.

2 I. Assistant Secretary of State Shaw, "Cultural Cooperation Program of the Department of State," Department of State Bulletin 2 I 25 ( 33 May 1944).

22. Letter to Sir John Maud from R. F. Adam, 23 October I946; “Unesco Policy,” BWI/29, UK National Archives, Public Record Office, Kew.

23. The U.S. delegation was headed by Congressman J. William Fulbright, and also included Archibald MacLeish; head of the U.S. Institute of Education Reconstruction John W. Studebaker; Mildred Thompson of Vassar College; and Grayson Kefauver of Stanford University. 
their British hosts thus noted that because cultural exchange was "a question which has always engaged its attention and that of French intellectuals ... France could not fail to appreciate the offer made to its Government by the British Government that [Britain] associate herself as a Host Nation." ${ }^{24}$ As one analysis of French Unesco policy has concluded, "specific instrumental objectives" informed France's ultimately unsuccessful push for a more "intellectual" agenda within Unesco. ${ }^{25}$ They secured some gains, however, when Paris was secured as the provisional seat of the new organization, partly at the urging of Leon Blum, who argued: "French culture has always been marked by a tendency toward universality ... Paris then remains one of the cities in the world where the future Organization would find a natural seat." ${ }^{26}$ Tension also arose in this framing phase of Unesco between the American and British positions, and while several of the American proposals on funding and voting were approved, the U.S. delegation was stung by its failure to secure on the basis of its large financial burden (furnished along the same scale as the United Nations) an American in the office of interim director general. ${ }^{27}$

A constitution derived from the British/American proposals was finally adopted. Unesco was to be convened in an annual general conference, and would work through national commissions, structured so that public associations and individuals were involved in the formulation and implementation of Unesco programs. The democratic approach to international affairs that informed this arrangement was obvious: one contemporary U.S. commentary noted that Unesco "with unmistakable intent... reaches for an ordering of individuals to individuals within a world organization in which national governments are secondary. ${ }^{{ }^{2} 8}$ This globalist approach was also reflected in the fact that while government delegations would attend the Unesco General Conferences, Executive Board, Directorship, and Secretariat positions would be occupied by individuals in an unofficial capacity.

The ratification of the Unesco constitution was reported favorably in many quarters within the United States. Representative Chester E. Merrow, who had been at the London conference, declared to Congress that Unesco would serve

24. Letter to Duff Cooper from J. Chauvel, 2 I August I945, quoted in Luther H. Evans, ed., The United States and UNESCO: A Summary of the United States Delegation Meetings to the Constituent Conference of the United Nations Educational, Scientific and Cultural Organisation, in Washington and London, October-November 1945 (Dobbs Ferry, NY, I97I), 2 I4-5. On French views, see Charles S. Ascher, Unesco Relations Staff of the Department of State, "Forces in the Development of the World Plan of UNESCO," I3 January I950, Records of the U.S. Delegation to Unesco I950-1954, Paris Embassy, France, FSP, RG 84, NA.

25. See William R. Pendergast, "Unesco and French Cultural Relations," International Organization 30, no. 3 (Summer I976): 453. See also H. H. Krill de Capello, "The Creation of the United Nations Educational Scientific and Cultural Organisation," International Organization 24, no. I (Winter, I970): 30.

26. Blum quoted in Sewell, Unesco and World Politics, 77.

27. Evans, The United States and UNESCO, I43.

28. Byron Dexter, "Unesco Faces Two Worlds," Foreign Affairs 25, no. I (I947): 391. 
as "one of the great foundation stones in the United Nations' structure." 29 Archibald MacLeish, also addressing Congress, reflected that Unesco's significance would be its practical contribution to international order: "Men [sic] who regarded international activity in the field of education as impossible in I9I9 now regard it as not only possible but essential ... the greater directness of Unesco's approach to the problem lies . . . in the new realization, not abroad in the world, that the mutual understanding of the peoples of the world is essential to the hope of peace ... the only hope for peace lies in the mutual understanding not of Foreign Offices alone but of the peoples themselves." $3^{\circ}$

On May 22, I945, the U.S. House of Representatives unanimously passed House Joint Resolution 305 in favor of U.S. participation in an international educational and cultural organization. Support among the American public was cited in government statements as substantial: 85 percent of the population supported U.S. involvement in Unesco in $1945 .{ }^{3}$ However, U.S. domestic media comment on the founding of Unesco and on the U.S. National Commission's first meeting shows mixed public opinion. Whereas key initiatives supported by the U.S. National Commission in I946 such as the review of school textbooks were discussed favorably in publications such as the Washington Post and the Christian Science Monitor, writers for the Chicago Daily Tribune derided textbook reform as antipatriotic and tantamount to propaganda, finding an audience with Americans skeptical toward the United Nations and the Truman administration's deepening international commitments. ${ }^{32}$ As Lawrence Wittner has noted, the immediate postwar period was one in which U.S. public opinion on international peace and the means to secure it was varied. Though many organized pacifist groups survived the war, and enthusiasm for forging peace through mutual understanding was strong, so also was a willingness to embrace power politics and a tendency to see global politics in increasingly Manichean terms. ${ }^{33}$

29. Congressional Record cited in Kolasa, International Intellectual Cooperation, I40.

30. Statement of Archibald MacLeish to the Committee on Foreign Affairs of the House of Representatives, reprinted in "The Role of Unesco in Our Foreign Policy," Department of State Bulletin 2508 (14 April 1946): 629.

31. Statement of William Benton to the Committee on Foreign Affairs of the House of Representatives, reprinted in "The Role of Unesco in Our Foreign Policy," Department of State Bulletin 2508 (I4 April I946): 626.

32. The condemnation of Unesco's educational program in America foreshadows the attacks by various patriotic groups in $195^{2}$ on publications about "world citizenship" that were distributed by Unesco to U.S. schools. On mixed media views of Unesco in 1945-1946, see "Global Minds Cry for Peace via Propaganda," Chicago Daily Tribune, 25 March I 947; "Unity beyond Politics," Christian Science Monitor, I4 December I945; Malvina Lindsay, "Classroom Jingoism," Washington Post, 25 April 1946. For an explanation of U.S. government policy on educational reform and the ideology of global integration, see Klein, Cold War Orientalism.

33. Lawrence S. Wittner, Rebels against War: The American Peace Movement, 1933-1983 (Philadelphia, I984): 99-100, 108, I79. 
Unesco's first general conference was held in late 1946. A budget of $\$ 6,950,000$ was approved for the first year's program..$^{34}$ In his report to the State Department, conference delegate and Assistant Sectary of State William Benton affirmed that the "cultural democracy" of the new organization was in the spirit of U.S. objectives..$^{35} \mathrm{He}$ argued that Unesco

can be a major force in the security program of the United States, and in the furtherance of the broad objectives of American foreign policy. ... Power in today's world is not merely economic power and military might. It also lies in the field of ideas. As older empires lose economic and military power, and as new ones emerge, they are eager to gain strength on this new frontier-the frontier of the mind-where peace and security can be waged..$^{36}$

The 1946 General Conference has been cited in several accounts as the beginning of indirect Soviet hostility toward Unesco, though historical sources and subsequent historical studies reflect conflicting views of how keenly the Soviet government followed Unesco's progress. ${ }^{37}$ Yugoslavian delegate Vladislav Ribnikar was assumed to have been speaking for Soviet views at the 1946 conference when he condemned the lack of acknowledgement that dialectical materialism had received in the discussions, though ultimately indifference was more characteristic of the Soviet approach to Unesco in this period..$^{38}$ Indeed, the activities of Eastern bloc delegations in this period were at one point characterized as fairly inconsequential, one newspaper editorial depicting the delegates themselves as "substantive refugees" in Paris who "say nothing that may get them recalled home and nothing that would arouse American ire." ${ }_{39}$

In its first two years, Unesco's activities included researching international education programs; sponsorship of the International Council of Scientific Unions; surveys of international library facilities; exchange and distribution of publications; and sponsorship of an international conference on the popularization of science in $1947 .{ }^{\circ}$ Cultural and intellectual reconstruction, especially of

34. Unesco, "General Conference ist Session, Held at Unesco House, Paris, 20 November to ro December, I 946 ," $256-7$, http://unesdoc.unesco.org/images/oo i i/oo I I 45/I I 4580e.pdf. In two years the budget had risen only marginally, by less than \$I million, with large contributors such as the United States and Britain allocating far less to Unesco than to their national cultural programs. See Unesco, "Records of the General Conference of the United Nations Educational, Cultural and Scientific Organisation 3rd Session, Beirut, I948," vol. 2, Resolutions, 39, http://unesdoc.unesco.org/images/oo I I/oo I I 45/I I 459e.pdf.

35. Unesco, "General Conference ist Session," 64.

36. William Benton, "Report on the First General Conference of Unesco," Department of State Bulletin 2720 (5 January I947): 20-2 I.

37. Armstrong, "The Soviet Attitude toward Unesco" has a slightly different explanation from Sewell, Unesco and World Politics.

38. Benton, "Report on the First General Conference of Unesco," 2 I.

39. T. H. White, "Unesco Is Dying," Continental Daily Mail, 25 July I95०. This is a sad irony given that Czech, Polish, and Yugoslavian exiles had been associated with the Unesco project from 1942.

40. Sewell, Unesco and World Politics, 92-5. 
Germany, and the facilitation of information flows across national borders (advocated by prominent American delegates such as Benton and MacLeish) were stated policy priorities of Unesco's temporary postwar recovery programs..$^{4}$ School textbook revision was one practical initiative through which international understanding between peoples was expected to emerge. The United States and Canada undertook to purge "traces of nationalist bias" against each other in the historical canon of their respective educational systems, despite the controversial nature of textbook reform proposals for some sectors of U.S. public opinion, as noted above. ${ }^{42}$ Textbook reform was mired in controversy for the Unesco members despite its relatively modest objectives when a dispute emerged over a Mexican proposal (posed unsuccessfully as a resolution in the General Conference) that the history of colonialism in Western textbooks might also be reassessed "in the manner and to the extent necessary to secure [future] peace and international understanding." ${ }^{43}$

At the Paris General Conference in 1946, the U.S. delegation had argued that freedom of international information should be a policy priority in Unesco. ${ }^{44}$ The Department of State was sufficiently supportive of the principle that it established the Committee of Consultants on Mass Media in 1946, charged with determining "the means by which the mass media may be of more positive and creative service to the cause of international understanding and therefore of peace." ${ }^{45}$ These U.S.-sponsored priorities seem to have been successfully promoted in Unesco; the 1947 budget shows that the funding allocated to mass communications projects was $\$ 596,765$, higher than the funding of the Educational, Cultural, and Scientific Reconstruction; Education for International Understanding, Exchange of Persons; Natural Science; and Libraries divisions combined..$^{6}$ This emphasis on freedom of information attracted criticism from the postcolonial states in Unesco, as freedom of information seemed likely to exacerbate the informational imbalance that was already tilted toward the United States in international communications and media. ${ }^{47}$ Americansupported resolutions on freedom of information in Unesco and the United Nations during 1946 were also described by an Eastern bloc delegate as "fascist," ${ }^{8}$ while the Yugoslavian delegate charged that "a whole series of proposals

4I. "United Nations Educational, Scientific, and Cultural Organization," International Organization I, no. 3 (I947).

42. See Richard W. Burkhardt, "The Soviet Union in American School Textbooks," Public Opinion Quarterly I I, no. 4 (1947-48): 567-7I.

43. Wells, The UN, Unesco and the Politics of Knowledge, I 2 I-7.

44. Unesco, "General Conference ist Session."

45. Report of the US National Commission for Unesco with Letter of Transmittal from Assistant Secretary Benton to the Secretary of State, United States in the United Nations: Report Series 4 (Washington, DC, I946), I3-I4. 46. "Resolutions Adopted by the General Conference during Its Second Session, Mexico,

November-December I 947," http://unesdoc.unesco.org/images/oo I i/oo I I 45/I I 4580e.pdf.

47. Sathayamurthy, The Politics of International Cooperation, 156.

48. Byron Dexter, "Yardstick for Unesco," Foreign Affairs 28, no. I (I949): 57. 
by the Preparatory Commission, misusing the principle of 'free flow of ideas,' provides for the penetration of the masses by a propaganda devised by the adversaries of peace and the instigators of new wars." 49 A year later, the Polish delegation proposed a countermotion in the general conference criminalizing "war propaganda" to prevent the articulation of "nazi or fascist ideology" under the freedom of information provisions. It was blocked by Western states given the likelihood that it would restrict their own information programs in the Eastern bloc, these contending images of "information" and "propaganda" highlighting the extent to which the combative language of the Cold War had infused Unesco proceedings. ${ }^{50}$

In late 1948, the American delegation intensified its efforts to extract deeper commitments to the exchange of information by Unesco. Key foreign-policy initiatives of this year strengthened U.S. interests in favorable international publicity. Public opinion within the United States had been effectively mobilized in favor of the European Recovery Program in $1947-48$, such that "a country that had seemed to be losing interest in international affairs was brought to see itself as the dominant and responsible force in the non-communist world ... the pattern of events in Eastern Europe, the failure of great-power negotiations over Germany-all of these frustrating and disappointing developments were represented to the American people as the products of Soviet betrayal and aggression." ${ }^{\text {II }}$ I 948 marks an important turning point in the tone of American cultural relations that corresponded to the United States' more activist approach in broader foreign-policy priorities, with the pivotal National Security Council Memorandum $\mathrm{Io} / 2$, for example, instructing the CIA to launch a covert counterpropaganda and cultural subversion program against the Soviet bloc. ${ }^{22}$ The Smith Mundt Bill (Public Law 402) of January I 948 provided a legislative basis for the increasingly structured and activist intentions that cultural diplomacy was framed around. ${ }^{53}$ A more selective image of the United States was being crafted for international audiences, as the State Department instructed

49. Sewell, Unesco and World Politics, I4I.

50. Wells, The UN, Unesco and the Politics of Knowledge, 66-69; "Poland Attacks U.S. Position at Unesco Parley," Chicago Daily Tribune, I2 November 1947.

5I. Richard M. Freeland, The Truman Doctrine and the Origins of McCarthyism: Foreign Policy, Domestic Politics, and Internal Security 1946-1948 (New York, 1985), 8-9.

52. The CIA's budget increased nearly fourteen-fold between 1949 and I $95^{2}$, highlighting the significance of counterpropaganda and subversion in the prosecution of the early Cold War. Frances Stonor Saunders, The Cultural Cold War: The CIA and the World of Arts and Letters (New York, I999), 40-4I.

53. One witness cited cultural diplomacy as a basis to block Soviet expansion: "We have been forced to take our story directly to foreign people, many of whom live under regimes hostile to our country and what it stands for. This we have done by telling our side of the story direct to foreign people by every means in our power." Unattributed, "Statement of Principal Witness for the Office of the Assistant Secretary for Public Affairs, International Information and Educational Exchange Activities," Pursuant to Public Law 402, I-2; Records Relating to the International Information Activities 1938-1953, General Records of the Department of State, RG 59, NA. 
American libraries abroad to make a special effort to gather and display literature that refuted Communist doctrine; began to name American citizens who traveled to or spoke in favor of the Soviet Union; and rapidly enhanced official U.S. short-wave radio broadcasts to overcome Soviet jamming. ${ }^{54}$ George V. Allen had succeeded William Benton as assistant secretary of state for public affairs in January 1948 , and he reinforced the stronger line on U.S. publicity abroad by declaring that Cold War neutrality was an inherently illegitimate political position for any government to adopt..$^{55}$

In November 1948, with the U.S. airlift of supplies to a blockaded Berlin still under way, a policy paper to Washington from the U.S. delegation to the Unesco General Conference reported their repeated failure to garner strong support among Unesco members for U.S.-sponsored policies of freedom of information. Limited progress had been achieved, in the form of advisory studies of technical and organizational problems in communications, but the U.S. delegation was frustrated by Unesco's failure to take any significant substantive steps in mass communication. In particular, they hoped to extract Unesco-authored statements of condemnation of Soviet advances in Eastern Europe.$^{5}$ As the former head of the Department of the Exchange of Information at the secretariat reflected, American efforts had been blocked by Continental European delegates, who remained sensitive to the manipulation of the information for political purposes despite their own concern over Soviet expansionism. ${ }^{57}$

The outbreak of war in the Middle East in 1948 also did not bode well for the Beirut General Conference, with a last-minute executive meeting called to determine whether it would still be appropriate to convene the General Conference in Lebanon at all in a time of war, particularly in light of the fact that Lebanon's opponent, the provisional state of Israel, had just voiced its intention to join Unesco. ${ }^{8}$ The American delegation's attitude to Israel's membership was

54. "U.S. Protests Soviet Jamming of Voice of America," Department of State Bulletin 3503 ( 5 May i 949); George V. Allen, "U.S. Information Program," Department of State Bulletin 32 I 8 (I 8 July I948); on the selection of library materials, see Robert L. Johnson, "Press Statement," Report on the Operation of the Overseas Book and Library Program, fuly I5, I953, Department of State International Information Administration, Unpublished Pamphlet, Lauinger Library General Collection, Georgetown University, Washington, DC, 5-6.

55. Allen, "U.S. Information Program," 90.

56. United States Delegation to Unesco, "Position Paper on Unesco Program Concerning Freedom of Information," I 7 November 1948, 2, Unesco 1945-1949, DF, General Records of the Department of State, RG 59, NA. See also John B. Whitton, "Cold War Propaganda," American fournal of International Law 45, no. I (January I95 I): I 5 I-3.

57. Theodore Besterman, Unesco: Peace in the Minds of Men (London, 1951), 63.

58. J. L. Henderson, Unesco in Focus, American Education Fellowship Freedom Pamphlets Series (I949), 33. See also United States Delegation to the Third Session of the General Conference of Unesco (U.S. Delegation), "Report on General Political Relations during Third Session of the Unesco General Conference, Beirut," I, Unesco I945-I949, DF, General Records of the Department of State, RG 59, NA. See also Grayson Kefauver, The Pursuit of Education: An Autobiography (New York, I981), i78. 
largely pragmatic. A U.S. preparatory report on the Arab states in Unesco instructed the delegation to court influence with this group, noting the "possibility of influencing them separately and also weaning them away from the Latin-American block. In future conferences much can be done with this group (which is basically sympathetic to the U.S.) by careful exposition of our views and a show of understanding for theirs." ${ }_{59}$ The UK delegation was divided on the appropriateness of Israel's candidature given their official policy of diplomatic nonrecognition in this period; however, a British memorandum rather contrastingly depicts the United States as encouraging Israeli membership in Unesco, quoting a State Department representative as claiming that "it would be contrary to the spirit of the Constitution of Unesco . . . if it were made impossible for the Israeli guests to come."60 Despite these friendly statements, when the nongovernment Israeli observers who had been invited to the General Conference as a compromise with the Arab members were turned away at the border of Lebanon, the U.S. delegation made no protest.

The I 948 General Conference in Beirut was thus rapidly becoming a symbol of the instrumentalism of cultural relations and the rise of power politics in Unesco. George Allen, in his capacity as chair of the U.S. delegation, was briefed by the Department of State to be mindful of:

The growing importance of Unesco and our vital interests in the Organization and its objectives carry with them the obligation to assume a leading role in the proceedings of the Conference.... The members of the Delegation should, individually and collectively, take the initiative in supplying information based on the resources and experiences of this country which may be of assistance in promoting the objectives of Unesco.

From the outset the United States has demonstrated forcefully its desire to collaborate in this program through substantial contributions of thought, effort and funds on the part of its citizens, both public and private. Through these efforts the United States has assumed leadership in the preliminary tasks of Unesco and will undoubtedly be called upon to continue to maintain this role of leadership if Unesco is to accomplish its purpose. However, in a truly cooperative international enterprise such as this one an overriding influence by any single country would obviously detract from the usefulness

59. Arthur A. Compton, "Confidential Report on Third Session Unesco General Conference, November-December 1948," I, Unesco 1945-1949, Department of State Decimal Files (hereafter DF), General Records of the Department of State, RG 59, NA. On the emerging voting bloc, see also U.S. Delegation "Report on General Political Relations during Third Session of the UNESCO General Conference, Beirut," 4-5, Unesco 1945-1949, DF, RG 59, NA.

6o. Unattributed report on Executive Board meeting of ${ }_{5} 5$ October I948, "Third Session of the Unesco General Conference, Beirut, November, 1948," FO924/648, UK National Archives, Public Record Office, Kew. 
of the Organization, and it is important to avoid giving the impression that the United States wishes to wield such influence. ${ }^{6 \mathrm{r}}$

Reports from the conference highlight that the U.S. delegation was instructed to exert political and institutional leverage over the other delegations. For instance, the head of the U.S. delegation in Beirut on the politics of Unesco was advised that:

It should be noted that the characteristics of its leadership is shifting slightly to the "latin" (both American and European) from its original "anglo-saxin" [sic] domination. One of the most effective ways of dealing with this group is to maintain effective U.S. participation at all times by forceful well-briefed persons with great influence. On really vital issues, many (if not most) Board members can be influenced through their governments (but this must be done discreetly and not too often). ${ }^{62}$

What is most telling about Beirut in the context of the emerging Cold War tensions within Unesco is the extent to which the United States was unsuccessful in its attempts to shape the outcomes of the conference. A postcolonial caucusing bloc was able to secure the director generalship for their preferred candidate Jaime Torres Bodet, former foreign and education minister of Mexico. He was not the United States' first choice. The U.S. delegation also complained to their superiors of the support given to postcolonial "neutralism" by the Italian and French delegations, who appeared to have adopted a more conciliatory stance toward the Soviet bloc and made constant objections of their own to American and British "cultural imperialism." One report on the fracturing of Unesco noted that the postcolonial bloc had been encouraged in their anti-American stance by the social democracies of Continental Europe, sensibilities "greatly influenced by French intellectual leadership." ${ }_{3}$

Beirut had signaled that Unesco's "apolitical” mandate made the organization, ironically, a "low risk" but visible framework in which to stake ideological claims; its universalist foundations were open to interpretation and could be valuably turned to narrower political purposes. The general conference held in Florence in June I950 was consumed by debates over new memberships, as the Eastern European bloc lobbied to have the Nationalist Chinese delegation to Unesco replaced by a delegation from the Communist mainland. After being outvoted on the issue, the three Eastern bloc states boycotted the rest of the meeting and did not return as active members before they resigned in $195^{2}$. The

6r. Unattributed letter to George V. Allen, Chair of Delegation to Unesco General Conference, 8 November I949, I, Unesco I945-1949, DF, General Records of the Department of State, RG 59, NA.

62. Compton to Allen, "Confidential Report on Third Session Unesco General Conference, November-December I 948," 2, Unesco I945-1949, DF, RG 59, NA.

63. Ibid., 2. See also Dexter, "Yardstick for Unesco." 
diplomatic struggle over the Korean War had also erupted by the end of the conference, and proved a more divisive incident for Unesco than Beirut had been.

The invasion of South Korea by the Communist North seemed in Washington to be a vindication of the containment doctrine which stated that Soviet expansion was virtually guaranteed unless strong counterbalancing in all spheres of international activity could be undertaken - the realm of cultural relations included. The language of previously progressive internationalists in the American cultural relations sphere such as Waldo Leland, Luther Evans, and George Stoddard - the latter by then referring to Unesco as a "counterforce" in a "war of ideas" - had hardened into effective support for a "containment" approach in U.S. cultural relations. ${ }^{64}$ Although the intervention in Korea was legally a "police action" conducted by the United States on behalf of the United Nations, the language that the U.S. administration applied to it has been described by Michael Hunt as involving "stark and sweeping terms usually reserved for crusades." ${ }_{55}$ President Truman's message to Congress on the outbreak of war thus charged that the global psychological implications of the conflict were paramount: "Korea is not only a country undergoing the torment of aggression-it is also a symbol. It stands for right and justice." ${ }^{166}$

Shortly after the declaration of war on July 25, I950, the American Unesco delegation urged the institution to unequivocally declare support for the allied operations. The United States made its request by calling an emergency Executive Board session just one month before the next scheduled meeting, which dismayed the British, who professed to be "considerably embarrassed" by indications that the United States "appear to wish to involve Unesco in propaganda work." ${ }^{{ }_{7}}$ Despite the fact that the intervention had been legitimated in the UN Security Council, many of the United States' allies nonetheless questioned the notion that Unesco ought to participate in the engagement itself. The "philosophical" distance between British and American conceptions of Unesco's rightful role is reflected in a Foreign Office memorandum of that August, in which it was speculated that the haziness of America's goal would lead to the nation's inevitable disappointment and frustration with Unesco. ${ }^{68}$ While Britain and the

\footnotetext{
64. Ninkovich, The Diplomacy of Ideas, I 54-5.

65. Michael H. Hunt, Ideology and U.S. Foreign Policy (New Haven, CT, I987), I 58.

66. "Text of Truman Message to Congress on State of Union," New York Herald Tribune, 9 January $195 \mathrm{I}$.

67. Draft Telegram "August 1950," "Unesco and the Korean Situation," FO 371/8890I, UK National Archives, Public Record Office, Kew.

68. Draft Letter to F. R. Cowell from D. S. Cape, I6 August I950, I-2, "Unesco and the Korean Situation," FO 37 I/889or, UK National Archives, Public Record Office, Kew. See also Unesco Relations Staff (Unesco Staff), Paris Embassy, "Report on the Unesco Secretariat's Carrying Out of Unesco Executive Board Resolutions on Korea," 7 March I95 I, 2-3, Records of the Unesco Delegation I950-I954, Paris Embassy, France, FSP, RG 84, NA. On Torres Bodet and the Unesco secretariat's views of the role of Unesco in Korea, which conflicted with the United States' instrumental view of culture, see also Sewell, Unesco and World Politics, I 49.
} 
Commonwealth quietly voiced their concerns, however, the caucusing bloc of Latin American, Near Eastern, and southern European states, espousing neutrality, was more public in expressing their consternation. ${ }^{69}$

The United States hoped to secure agreement on an information program to be conducted under Unesco's auspices, which would inform the international public of the nature of the conflict and the United States' efforts to contain Communist expansion..$^{7}$ The U.S. Unesco delegation reported that after transmitting their suggestions for action on Korea with their request for a special meeting to the Executive Board "excitement" ensued, and that the request "was immediately interpreted, by those all too ready to criticize "American domination of Unesco,' as a U.S. effort to change the nature of Unesco.... This brought an immediate negative reaction from the French Foreign Office. ... The opinion of the French is that any Unesco action on this matter should be taken upon requests received from the appropriate organs of the UN." ${ }^{1}$

The emergency meeting was called for August 26 by Director General Torres Bodet, who was by that point a focal point for American lobbying. Shortly after the outbreak of war in Korea, Torres Bodet had staked his position that Unesco's role in Korea could be in a postconflict capacity only. American policymakers speculated about the causes of ongoing skepticism toward its proposals in the weeks leading up to the meeting, reporting that "it seems apparent that this feeling is shared widely among Europeans who emphasize the concept of Unesco as an international cultural organization rather than primarily a political instrument." ${ }^{2}$ After William Benton (who was by that time a U.S. senator) appeared at the Florence General Conference urging on Unesco a more proactive form of anticommunism Torres Bodet temporarily resigned, citing unacceptable pressures on his office. ${ }^{73}$ In response, an internal American memorandum branded him an ideologue and a manipulator, asking: "How much he is influenced by the philosophy of 'Neutralism' and how much by the pressure of or desire to please those opposing the U.S." 74 American staff at the Unesco headquarters in Paris hoped some leverage could be gained by recalling (and exaggerating) their role in securing Torres Bodet's election after the failure of their own preferred candidate: "The key part played by the U.S. in the election of Torres Bodet as Director General should be recognized and used. In him we

69. Kolasa, International Intellectual Cooperation, I55.

70. See, for example, Howland H. Sargeant, "Major Tasks of Unesco in Establishing Communication among Peoples of the World," Department of State Bulletin 4055 (I January I95I).

71. Unesco Relations Staff, Paris Embassy (Unesco Staff), "Report of Activities at Unesco House for the Week Ending July 29, I950," 4 August 1950, 2-3, Records of the Unesco Delegation I950-I954, Paris Embassy, France, FSP, RG 84, NA.

72. Ibid.

73. Julian Huxley, "Unesco: The First Phase," Manchester Guardian, io August I950.

74. Unesco Staff, "Report on the Unesco Secretariat's Carrying Out of Unesco Executive Board Resolutions on Korea," 7-8, Records of the Unesco Delegation 1950-1954, FSP, RG84, NA. 
have a leader who is not necessarily going to be sympathetic to the U.S. views. He appears to be independent and more than slightly influenced by his LatinFrench background.... [However] Being a man of no small political experience, he should also be susceptible to political influence (applied appropriately) on the most vital matters." 75 The British, on the other hand, worried that the fight in Florence had produced a "highly charged emotional atmosphere," and were aware that "we and the United States clearly bear chief responsibility for the departure of Torres Bodet" from the conference. ${ }^{6}$ The French delegation emerged, unsurprisingly, as one of the strongest critics of the United States' "propaganda" proposals for Korea, ${ }^{77}$ and the majority of delegations supported Torres Bodet's initially defiant stance against the United States, preferring either a clearly "civilian" Korea program that maintained Unesco's independence from Cold War politics, or none at all. Despite this opposition, and with clear confidence that America's international "information" did not constitute "propaganda," the U.S. delegation dismissed such arguments as a "more apparent than real ... [concern] around the question of where information stops and propaganda begins." 78

After difficult Executive Board debates in August, Torres Bodet crafted a resolution on Unesco's role in Korea that emphasized Unesco's interest in a postwar reconstruction role, which many members would support, but also included vaguely worded war information provisions. Although the director general tried to locate the resolution within the spirit of the constitution and the "normal program" of Unesco, controversy raged on. Twenty-three member states had submitted comments on the compromise resolution. Only six were positive, four were openly negative, four expressed no opinion but merely acknowledged the event, and two argued that while the UN action in Korea was warranted, Unesco's involvement was not. ${ }^{79}$ The U.S. delegation interpreted the director general's wording as supporting U.S. plans. ${ }^{80}$ U.S. delegates reported to Washington that a process had begun by which it could "[u]se the Korean case

75. Compton, "Confidential Report on Third Session Unesco General Conference, November-December i 948," 3, Unesco 1945-1949, DF, RG 59, NA.

76. Paris Telegram No. $5^{83}$, p. 2; "Debate on Resignation of Unesco Director-General Dr. Jaime Torres Bodet Because of Vote against His Budget, Followed by Other Resignations from the Executive Board; Constitution of the ILO; Staff Rules of the FAO and Unesco," FO 371/ror 529, UK National Archives, Public Record Office, Kew.

77. Unesco Relations Staff, "Report of Activities at Unesco House for Week Ending August 25, I950," 29 August 1950, 2, Records of the Unesco Delegation 1950-1954, Paris Embassy, France, FSP, RG 84, NA.

78. Ibid., I; On the rejection of propaganda, see Nancy E. Bernhard, "Clearer Than Truth: Public Affairs and the State Department's Domestic Information Campaigns, I947-1952," Diplomatic History 2 I, no. 4 (Fall 1997); J. Michael Sproule, Propaganda and Democracy: The American Experience of Media and Mass Persuasion (Cambridge, UK, I997).

79. On the views of member states, see Kolasa, International Intellectual Cooperation, I 56-7; Sewell, Unesco and World Politics, I49.

80. Unesco Relations Staff, "Report of Activities at Unesco House for Week Ending August 25, I950," I, Records of the Unesco Delegation I950-I954, FSP, RG 84, NA. 
as a lever to improve and strengthen the orientation of the Secretariat toward the United Nations and 'Peace and Security.' Militant Pacifism, not 'Neutralism' nor academism should be the prevailing spirit" of Unesco's message. ${ }^{8 r}$ Tensions within the Executive Board also led the U.S. Unesco staff to articulate some longer-term objectives within the organization: "The Korea question is having a salutary effect... the Secretariat members are now more than ever before being forced to 'stand up and be counted' as to their personal politics in favor of either the Eastern or Western form of democracy. . . . It is needless to emphasize the importance in this connection of the appointment of a first class American [Deputy Director General]." ${ }^{2}$

By January I95 I, an initial sum of $\$$ I 75,000 was approved for "emergency relief and eventual reconstruction in the field of education, science and culture for the people of Korea" and also, crucially, for "information through Unesco media and through all Unesco's educational facilities ... on the necessity for Collective Security." ${ }_{3}$ Work began soon after on publicity materials interpreting the conflict in Cold War terms, despite that fact that the project was still unpopular and that policy planning meetings were "sometimes far from calm." ${ }_{4}$ Ironically, after pressuring Unesco into adopting a program of global information on behalf of the Korean War and alienating the majority of the other delegations in the process, the Department of State had begun to question Unesco's usefulness for furthering U.S. global objectives. In the middle of I95 I, for instance, one American delegate to Unesco warned his superiors that Unesco should be a more minor policy priority for the United States because the organization had lost credibility with some of its most important official and public supporters in Europe. ${ }^{85}$

Between I95 I and 1952 the Eastern bloc delegations began to condemn U.S. dominance in Unesco more forcefully in their official media. The USSR had remained noncommittal on questions of Unesco in the late I940s, in keeping with its isolationist stance on bilateral cultural relations in these years, but broke its silence on Unesco with a series of articles after 1950 condemning American "dollar imperialism." Soviet intentions toward Unesco have been defined in one American study of Unesco proceedings and Soviet media as basically defensive up to this point, as Unesco's suitability for the propagation of communism was

8I. Unesco Staff, "Report on the Unesco Secretariat's Carrying Out of Unesco Executive Board Resolutions on Korea," I 2, Records of the Unesco Delegation I950-I954, FSP, RG 84, NA.

82. "Records of Activities in UNESCO House for the Week Ending August 4, I950," 5, Records of the Unesco Delegation I950-I954, Paris Embassy, France, RG 84, NA.

83. Unesco Staff, "Report on the Unesco Secretariat's Carrying Out of Unesco Executive Board Resolutions on Korea," I, Records of the Unesco Delegation I950-I954, FSP, RG 84, NA.

84. Ibid., 2-3.

85. Letter to Charles A. Thomson from Arthur A. Compton, 9 February i 95 I, 2, Records of the Unesco Delegation I950-I954, Records of the Paris Embassy, France, FSP, RG 84, NA. 
"probably never very high ... [rather] the USSR hoped to neutralize Unesco's effect on world opinion." ${ }^{86}$ Questions of membership arising from deposition of instruments of acceptance by Spain, Japan, Austria, and West Germany had elicited numerous criticisms and, as noted above, led ultimately to the Eastern bloc's suspension of membership in $1952 .{ }^{87}$ The comments of one contemporary U.S. commentator situate Eastern bloc and Soviet statements on the applications as playing on the foundational contradiction between the universalist language of Unesco's founding and the narrow purposes that this language would turn out to serve. He notes: "It may seem paradoxical that, at the same time that they used the appeal of universality as a device to enlist sentiment for the admission of Communist China, Soviet spokesmen [sic] bitterly opposed this same sentiment when it favored the admission of nations which they sought to exclude from UN bodies." ${ }^{88}$

In $195^{2}$, tensions over a budget freeze imposed by the United States and Britain led to Torres Bodet's permanent resignation. He was replaced by Luther H. Evans, an American, who had effectively distanced himself from the State Department by opposing Senator Joseph McCarthy's campaign to remove suspected Communists from government ranks, but whose appointment appeared nevertheless to the United States' critics in Unesco as yet another manifestation of American dominance. British Foreign Office records note France's "fury" at the election, noting the "strength of anti-American sentiment... inspired by the evident fact that [Evans] would not be the staunch upholder of French culture and the French language which the French had in Torres Bodet." ${ }_{9}$ Meanwhile, combating "neutrality" in Unesco remained a significant preoccupation for the Department of State-one aide-de-mémoire of August $195^{2}$ noted that neutralism and anti-Americanism were the key problems of Unesco, implying they were essentially the same thing..$^{\circ 0}$

With the appointment of an American director general, Washington's hopes that Unesco could further U.S. interests were further revived, as reflected in their attempts to amend Unesco's constitution by reconstituting the Executive

86. Armstrong, "The Soviet Attitude toward Unesco," 2 I 7-33. This is supported by at least one other account stressing Soviet cultural isolationism prior to I952. Frederick C. Barghoorn and Paul W. Friedrich, "Cultural Relations and Soviet Foreign Policy," World Politics 8, no. 3 (April 1956).

87. Letter to the Unesco Director General from Polish Ambassador in Paris, 5 December 1952; "Admission of New Members to Unesco; Admission of Spain in Spite of Protests; Withdrawal of Poland from Unesco; Speculation as to Reasons for Portugal's Not Applying to Join,” FO371/95913, UK National Archives, Public Record Office, Kew.

88. Armstrong, "The Soviet Attitude toward Unesco," 22.

89. Unattributed, "Unesco Director General," I9 June I953, I; "Candidates for DirectorGeneralship of Unesco; Election of Dr. Luther Evans, of the USA, as Director General at a Special Session of Unesco in July I 953," FO 37 I/I07236, UK National Archives, Public Record Office, Kew.

90. Robert S. Smith to Charles A. Thomson, "Report on Trip to the United States, July 2 I-August 8, I952," I 3 August 1952, 3, Records of the U.S. Delegation to Unesco I950-1954, Paris Embassy, France, FSP, RG 84, NA. 
Board as a body of government representatives. Following the death of Stalin and in a new spirit of openness to cultural relations, the Soviet Union and two Soviet republics joined Unesco in $1954 .{ }^{9 \mathrm{I}}$ British records on the admission of the USSR show that certain tensions underlay their support for the United States in this period. While the legitimacy of Soviet inclusion under the doctrine of Great Power representation was duly noted by the British, and some officials hoped that a warming of East-West relations would ensue, other government sources anticipated that Unesco would decline into obstructionism and anticolonial propaganda when the USSR joined. ${ }^{92}$ Another memorandum expressed the likelihood of Unesco's complete subversion by the USSR due to the "appallingly vague terms of reference [that] were drafted in London," lamenting that because the United Kingdom was instrumental in Unesco's establishment "it is therefore difficult for Her Majesty's Government to pull out without a very good excuse." 93 The United States, in keeping with a strategy of institutional dominance, greeted the news with instructions that the U.S. delegation to Unesco "do all possible to fill vacant high ranking posts in Unesco, in order to forestall a Russian demand to place its nationals in these posts." 94 Of this period one historian has subsequently noted that "For years the façade of nongovernmentalism [had] stood despite its widening fissures," but even this crumbled after I954's developments. ${ }^{95}$

\section{Conclusion}

Recent historical debates have illustrated the depth at which processes of culture, ideology, and persuasion shaped Cold War history, examining how the superpowers' foreign policy came to be determined by "carefully constructed

9I. Armstrong, "The Soviet Attitude toward Unesco"; Barghoorn and Friedrich, "Cultural Relations and Soviet Foreign Policy."

92. On the Soviet Union's "right" to join UN Specialised Agencies, see E. R. Warner, I3 November 1953, "Admission of Soviet Union to UN Specialised Agencies"; "UK and US Attitude to Application by Soviet Union to Join Some UN Specialised Agencies, Such as ILO, Unesco and WHO," FO37I/I07175. On the idea of Unesco as a "bridge" between East and West, see File Notes, "Membership of Unesco: Application by Rumania"; "Admission of Soviet Union and Soviet Bloc Countries to Membership of Unesco," FO 37I/I I 2606. On the role of great powers, see Draft Letter to B. Salt from H. F. Bartlett, undated (I954), "Admission of Soviet Union and Soviet Bloc Countries to Membership of Unesco," FO37I/I I2607. On Soviet subversion of Unesco, see "Soviet Bloc Tactics and Counter Measures at the General Conference of Unesco," I954; "Organizations: Soviet Propaganda on Disarmament and Soviet Bloc Tactics at Unesco: Briefing for UK Delegation,” FOıı Io/628. All Records from UK National Archives, Public Record Office, Kew.

93. E. R. Warner, "United Kingdom Contributions to Unesco," i July I955; "Visit of Dr.

Luther Evans, Director General of Unesco, to London 28 June I955: Foreign Office Views on

Unesco," FO 37 I/I I 7539, UK National Archives, Public Record Office, Kew. 94. Charles A. Thompson, Office Memorandum, 20 April 1954, Records of the U.S.

Delegation to Unesco 1950-1954, Paris Embassy, France, FSP, RG 84, NA. 95. Sewell, Unesco and World Politics, I43, I69. 
narrative[s] of progress, freedom, and happiness. ${ }^{~}{ }^{6} \mathrm{I}$ have sought to contribute to this existing literature by exploring the history of multilateral cultural relations within Unesco, a case illustrating America's Cold War cultural pragmatism and its effect on its geopolitical allies. In both the "cultural internationalist" and subsequent "cultural nationalist" phases of U.S. strategy in Unesco, cultural multilateralism was seen as a means to achieve U.S. influence. What changed was the fact that the United States was increasingly isolated by its allies as the postwar period progressed-a consequence of the broader dissipation of wartime political unity and the rise of alternative political agendas from among the United States' allies. Though some members of Unesco clung to the hope that cultural relations could operate beyond ideological struggles in this period, "nonalignment" was unsustainable under conditions of Cold War conflict and the institutional hegemony of the United States.

96. Laura A. Belmonte, "A Family Affair? Gender, the U.S. Information Agency, and Cold War Ideology, I945-1960," in Culture and International History, eds. Jessica C. E. GienowHecht and Frank Schumacher (New York, 2003), 80. 